\title{
Business Complexity, Business Strategy: Sustainable Business Performance Analysis
}

\author{
Tumpal Manik ${ }^{1}$, Hilda Rossieta ${ }^{2}$, and Lindawati Gani ${ }^{3}$ \\ $\left\{{ }^{1}\right.$ tmanyk@gmail.com, ${ }^{2}$ hilda.rosieta@ui.ac.id, ${ }^{3}$ gani@ui.ac.id $\}$ \\ ${ }^{1}$ Raja Ali Haji Maritime University, ${ }^{2,3}$ University of Indonesia
}

\begin{abstract}
The various problems of business complexity become problems faced by managers and company leaders, as a major trend must be managed well to maintain sustainable business performance. Analysis of sustainable business performance has been a constant debate in literature studies over the past few decades. Previous studies focused on deductive theory, based on literature and case studies. In contrast, this study used companies financial statement data to analyze sustainable business. The purpose of this study is to conduct an investigation business complexity on sustainable business performance. The results showed that business complexity negatively affects sustainable business performance, if the company's increasing complexity reflects the many challenges and problems of the business managed by managers. Furthermore, business strategy has a positive influence on sustainable business performance, this is shown by the performance achievements of managers turning investor capital into profit, as the main task of managers in the company to create economic added value by improving performance.
\end{abstract}

Keywords: business complexity, business strategy, sustainable business performance

\section{Introduction}

Sustainable business performance research has been seriously debated in various literatures over the past few decades such as the [1], [2], [3]. The study of business performance is always evolving from non-financial performance to financial performance [4], [5] and [6]. Recent literature has provided ample evidence of a much broader evolution of performance indicators in defining the achievement of sustainable business performance [7], [8], [9], [10], [11]. There are gaps in studies on business complexity and sustainable business performance analysis as the studies focuses more on deductive theory, case studies and analysis of literature on business practices and compare qualitative study results with theoretical models [12], [13]. Then, there is no standard as a more practical guideline on strategy and, planning in business activities [14], [15], [16]. In accordance with the demands of the business world, the process of adopting sustainable business strategies are increasing and growing [17], [18]; [19], [20], [21], [22].

Sustainable performance is expressed as a sustainable economy supported by the environment, society, and government. However, there is little research on how to achieve sustainable business and financial performance [16], [23]. Effectively and environmentally regulated companies are expected to produce sustainable performance to create added value for company owners with the aim of gaining the trust of the public and investors. [24], [25], stated that sustainable business performance using economic value added (EVA) and the application of effective enterprise risk management have a significant positive impact on 
business performance. Sustainable business performance is assessed based on four criteria: efficient production and distribution of goods and services; fixed asset intensity, and Marketto-book ratio and (iv) dividend payments [26], [27], [28]. Sustainable business performance strategies must be formulated for the company's needs in meeting current and future stakeholder demands. Business complexity in the disclosure of company performance information becomes the object of analysis [21], [29]. Disclosure theory is divided into two opposite directions: disclosure is long and technically useful because it contains complexity business information [30], [31], [32], and excessive and complex disclosures complicate understanding and obscure important information in financial statements [33], [34], [35]

This research aims to empirically test the influence of business complexity on sustainable business performance and answer the follow questions; (i) Does business complexity negatively affect sustainable business performance? (ii) Does a business strategy have a positive influence on sustainable business performance? (iii) Does the complexity of business and business strategy have an impact on sustainable business performance?

The objectives of this study are to test and investigate: (i) the influence of business complexity on sustainable business performance analysis; (ii) the influence of business strategies on sustainable business performance analysis and (iii) the influence of business complexity and business strategy on sustainable business performance.

Research contributions for this study consist of (i) providing empirical evidence of business complexity to sustainable business performance using quantitative data of a company's financial statement, response to criticisms that business complexity is very difficult to research, (ii) provide empirical evidence and support scientific studies in accounting, management and business through the analysis of sustainable business performance of business complexity, and business strategy, according to the characteristics of the company in Indonesia. (iii) add scientific information to academics, researchers and especially business people as practitioners managing the company's business.

\section{Literature Review and Hypothesis Development}

\subsection{Sustainable Business Performance}

Literature on the analysis of sustainable business performance using a company's financial performance is still a step, and opens up opportunities for academic researchers to conduct studies in this field. Sustainable business performance analysis studies are very important, to identify the effectiveness of management in managing, and developing a company in order to remain sustainable. Management and company leaders always strive to improve their performance, can provide an increase in the value of economic of a company to enable it to stay afloat until the company is sustainable. Sustainability becomes a strategic and integral part of business operations [36], [19], [18]

Sustainable concepts are very complex and wide ranging, so there is limited research on complexity and sustainability. According to [19], empirical studies of complexity and sustainability have improved, but only in certain contexts. One possible reason for the lack of sustainable business strategy research is that the company's sustainable strategy differs 
substantially in terms of internal and external factors (industry, sector, type of product or service, stakeholder demand, policies, internal structure and processes, etc.

Previous studies of sustainable business performance using measurements with economic value added (EVA) have had a significant positive impact on overall and sustainable business performance [24]. Sustainable strategies create sustainable business models. This in turn will create a competitive advantage for business organizations, by contributing effectively and appropriately to the company's business field in order to remain sustainable [37], [17]. Sustainable business model development is a requirement for a business strategy to maintain a company's stability. Developing several sustainable business strategies was found to be most beneficial, with each strategy providing different solutions to different challenges [37], [38]. Sustainable business within an organization is considered a unique process in running business operations. It will enable a company to achieve higher sustainable business performance, build better business in the eyes of stakeholders, lead to better decisions decision making as well as improved risk management control [39], [40]. Sustainable business within an organization leads to better business management and increase the growth of the organization's economic value and sustainable business performance.

\subsection{Business performance using economic value added (EVA)}

The concept of EVA is widely used by companies in evaluating performance [41], [42]; suggest that EVA is a measure of the company's performance that demonstrates management efficiency in turning investor capital into profit, i.e., creating economic value. EVA created a scheme that incorporates capital costs in performance evaluation, so that performance achievements turn investor capital into profit. This is one of the main foundations of management in a company to improve performance so that the company continues to carry out operational business activities [42], [24], [43].

Developing comprehensive and sustainable business performance in a variety of industries is an important task for management to manage the company considering various such as the economy, the environment, and society. However, in accordance with the demands of the development in the era of sustainability, considerations should be reviewed from the point of view of financial and non-financial performance, to achieve a better balance between sustainability and non-financial performance. This will have an impact on financial performance, which is key for company managers to develop business expansion in the global market and take advantage of technological advances in improving the company's business.

\subsection{Business Complexity and Sustainable Business Performance}

Research on the concept of complexity has been conducted over the years, but there is difficulty in defining it and there is no actual consensus. Complexity can be understood in different ways; not only in different fields but also having different connotations in the same field [44]. Some previous studies have criticized that there is no universally accepted definition or general opinion of the definition of complexity. Although the definition of complexity exists, it cannot be directly applied to specific organizations. Complexity is a general term used to help in understanding the problems facing complex organizations. Information complexity is embedded in the concept of quality accounting. 
Complexity translated into business economic activity into accounting disclosures [45]. Companies with large number of subsidiaries will have a high level of accounting complexity at the time of consolidation of financial statements. Complexity increases due to the complexity of the company's operations reported in financial statements, internal information and contract costs, as well as complex power and reputational risks [46], [34], [47]. Various problems from business complexity to unique problems faced by companies, must be managed with a sustainable business strategy. Complexity cannot be completely eliminated from an organization, but it can be reduced to a manageable level. Existing complexity management strategies can be set up according to the management control system approach [44] and [48].

The previous literature measuring complexity uses several proxies are namely: (i) characteristics of the company; company size, number of subsidiaries, number of segments, and Branch location [49]. (ii) the number of words in the 10-K report [30], [35], [50]; (3) readability of $10-\mathrm{K}$ report text of $10-\mathrm{K}$ file size (bytes) submitted as proxy for readability of annual report [36], [51], [52]. (4) measurement based on the number of words in the footnotes in the financial statements in recognition of income [53], [54]. (5) of the number of items in the XBRL report 10-K annual report [55], [45], [56], using the log amount of gross file sizes available and downloaded in the SEC filing, that file size correlates with document readability. Business complexity is a process that can adopt ongoing business and requires a more comprehensive investigation [57], [58], [32]. Business complexity greatly affects the company's performance so it will negatively impact sustainable business performance. Based on the description above, the development of the first, is as follows;

H1 : Complexity of the company's business has a negative influence on the analysis of sustainable business performance.

H1a : Complexity based on business characteristics of business segments, subsidiaries, company size and age of the company has a positive influence on sustainable business performance.

\subsection{Business Strategy and Sustainable Business Performance}

According to [19], sustainable business disclosure has implications for the business competitiveness strategy, i.e. the extent to which management implements a sustainable business strategy in improving economic value creation can be illustrated by the suitability of a sustainable business strategy. A poor sustainable business strategy will create a challenge between competitiveness and sustainability. It may result in the strategy being cancelled which will then impact the sustainability of the business performance. Sustainable business strategy development is the basis for the integration of business objectives, including social environment and business competition. Based on the activities of management planning, sustainable business strategy development is implemented to create the long-term economic value of the company's business, and like the stakeholders in the wider community [21]. The business strategy is formulated as a policy basis in meeting the needs of companies and stakeholders, to protect assets, and maintain the performance of resources as a future business strategy [59], [60]. Previous research by [36], studied the relationship between digital business strategy, sustainable strategy, and financial performance. Sustainable strategy served as a promoter in the relationship between managerial capability and financial performance but hindered the relationship between operational capability and financial performance. 
There is positive and significant support for the learning of organizational culture and digital organizational culture for sustainable business performance. Digital organizational culture mediates the relationship between organizational learning culture and sustainable business performance [61]. Other studies have developed literature theory studies on sustainable business performance related to sustainable business performance, claiming that there is a cultural role of organizational learning following the advancement of digitalization, as a basic reference for policy-making practitioners in making informed decisions. This study uses [62], namely: a) Efficient Production and Distribution of Goods and Services; b) Fixed Asset Intensity, c) Company Growth Rate (Market to Book Ratio) and d) Dividend Payment. The second hypothesis is as follows;

H2 : Business strategy has a positive influence on sustainable business performance.

The problem of business complexity on the performance of previously studied companies, revealed that executive characteristics and the existence of company coverage factors affect the company's performance [63], [64], [10]. The findings of a direct relationship between leadership style and company performance, show that professional leaders are needed in a competitive environment, the managers must be able to control the challenges of business complexity [65], [58]. The source of business complexity is interdependence of internal and external factors; local versus global operations; diversity of people and cultures including employees, customers, shareholders, and other stakeholders; information ambiguity that requires less obvious decision making and rapidly changing environmental uncertainty, changing dynamically [66], [67], [68], [69], found that improving corporate sustainability is based on economic performance in the short and long term profitability as a measure of economic performance, The third hypothesis developed is as follows;

H3 : Business complexity and business strategy have an influence on sustainable business performance.

\section{Research Methodology}

The research uses a quantitative method with secondary data, annual financial report data from company issuers published on the Indonesia Stock Exchange (IDX)., The data collected was from December 31, 2015 to December 31, 2019. There is no data for 2020 because many issuer companies had not published their financial statements on the IDX. Observation data with panel data was collected consisting of 1,215 data records from 243 company issuers. The companies had complete data and published their annual financial statements on the Indonesia Stock Exchange. This study grouped the population by industry classification (ICF), consisting of: ICF-1 as a classification of raw material producing industries, consisting of groups of agricultural, mining, raw materials and energy industries; ICF-2: classification of manufacturing industries, consisting of basic chemical industry, various industries, consumer goods industries and finally ICF-3 as a classification of service industry, consisting of property and real estate, infrastructure, utilities, transportation, finance, investment services and trade. The data was also tested by annual grouping. ICF grouping does not include financial, banking sector issuers, because sustainable business performance measurements have their own measurements and are different from this study.

\subsection{Measurement of Sustainable Business Performance Analysis}


The first measurement analyzes business performance using economic value added (EVA). The concept of EVA is widely used by companies in evaluating performance [70], [24], [41], [71], [42], suggest that EVA is a measure of the company's performance that demonstrates management efficiency in turning investor capital into profit, i.e., creating value. EVA creates a scheme that incorporates capital costs in performance evaluations. Use EVA by reducing the capital burden of net profit after tax. The cost of business capital is the Weighted Average Capital Cost (WACC) multiplied by the invested capital. In calculating the WACC, equity costs and debt costs are considered. Measuring business performance with EVA is becoming increasingly important, as it looks at the performance of investment achievements or investment portfolios. Sustainable business performance or business sustainability performance (BusSustain) is projected by measuring added value, namely economic value added (EVA).

EVA $=$ NOPAT $-[$ WACC $x$ Capital Employed $]$

Where; EVA (economic value added), sees the added value achieved by the company as a proxy to analyze sustainable business performance; NOPAT is net operating profit after tax; WACC is the weighted average capital cost, the capital used is the total assets after deducting liabilities without interest

The second measurement of sustainable business performance analysis using data from financial performance consists of: (1) measurement using working capital to total assets (WCTA), ratio measures the company's ability to meet short-term liabilities, the calculation of this ratio will be negative if the current liabilities are greater than current assets. WCTA is a current asset minus short-term debt and as a total asset. (2) measurement using retained earnings to total assets ratio (RETA), consisting of two components, namely retained earnings and total assets. The RETA measurement formula is a comparison of retained earnings with total assets. (3) measurement using earnings before interest and tax to total assets ratio (EBITTA), ratio measures the ability of the company to generate profit from the assets used, profit is income obtained from the operating activities of a company. The amount of profit is the entire revenue minus all operating costs taken from the company's assets. The higher the profit ratio indicates that the company's performance is getting better. The EBITTA formula is a comparison of pre-tax profit (EBIT) with total assets. (4) measurement using sales to total assets ratio (STA), the ratio detects the ability of the company's funds embedded in the overall assets that rotate in a certain period. This ratio measures the management's ability to use assets to generate revenue with the formula sales to total assets is a comparison of sales with total assets.

\subsection{Measurement Business Complexity}

Business complexity variables are used in this research because they reflect the many challenges and problems during business operations, and become the management's responsibility in managing the company. Management uses its internal control system to control the complexity of the business.

The first measurement of business complexity variables using proxy Fog Index developed by Gunning model 1968 by [72], [73]. The Fog Index is identified from the readability of financial information in the form of text (number of words and sentences) 
presented as business financial information in 10-K. Assuming that the text is well formed and logical, the Fog captures the complexity of text such as the application of regulations, description of company business information, number of business segments, subsidiaries, governance management, directors, employees. Business information is described in the form of words and sentences combining sentence length and average number of words per sentence referred to as business complexity in the company, The measurement of complexity using Fog Gunning proxy is formulated as follows:

\section{Fog Index $=0,4 \mathrm{x}$ (Number of Words/Number of WordSentences $)+100 \mathrm{x}$}

(Number of Words Hard words/Number of Words).

The measurement of both business complexity variables based on business characteristics consists of: (i) NumBus (number of business) based on the number of business segments owned by the company measured by the natural logarithm of the number of business segments still in operation; (ii) NumGeo (number of geographic) i.e. using the number of subsidiaries owned at different geographical locations and direct capital ownership, measured by the natural logarithm of the number of geographical segments, (iii) FirmSize; using the company's total sales value, measured by the natural logarithm of total sales; (iv) FirmAge; view business characteristics based on the age of the company is measured by logging the number of company ages.

Regression model of $\mathrm{H} 1$; testing the complexity of the company's business has a negative influence on the analysis of sustainable business performance, has a different direction to $\mathrm{H} 1 \mathrm{a}$; complexity based on business characteristics of business segments, subsidiaries, company size, company life has a positive influence on sustainable business performance. These two hypotheses are combined into one model, but the data processing and interpretation of the results corresponds to the direction of each hypothesis. The H1 regression model is prepared as follows:

$$
\begin{aligned}
\text { BusSustain }_{\mathrm{i}, \mathrm{t}}= & \phi_{0}+\phi_{1} \text { Complexity }_{\mathrm{i}, \mathrm{t}}+\phi_{2} \text { NumBus }_{\mathrm{i}, \mathrm{t}}+\phi_{3} \text { NumGeo }_{\mathrm{i}, \mathrm{t}}+\phi_{4} \text { FirmSize }_{\mathrm{i}, \mathrm{t}}+ \\
& \phi_{5} \text { FirmAge }_{\mathrm{i}, \mathrm{t}}+\phi_{6} \text { ROA }_{\mathrm{i}, \mathrm{t}}+\phi_{7} \text { Leverage }_{\mathrm{i}, \mathrm{t}}+\phi_{8} \text { BookValue }_{\mathrm{i}, \mathrm{t}}+ \\
& \phi_{9} \text { Accrual }_{\mathrm{i}, \mathrm{t}}+\phi_{4} \text { EarnVol }_{\mathrm{i}, \mathrm{t}}+\varepsilon_{\mathrm{i}, \mathrm{t}} \ldots \ldots \ldots \ldots \ldots \ldots \ldots \ldots \ldots \ldots \ldots \ldots \ldots \ldots \ldots \ldots \ldots \ldots \ldots \ldots \ldots \ldots \ldots \ldots \ldots \ldots \ldots \ldots \ldots \ldots \ldots \ldots \ldots \ldots \ldots \ldots \ldots \ldots \ldots \ldots \ldots \ldots \ldots \ldots \ldots
\end{aligned}
$$

Where: BusSustain (business sustainability performance) to see sustainable business performance based on financial data from performance and management responsibilities in managing the company, measurement using economic value added [74], [24]; Complexity is the complexity of a business measured by proxy fog index Gunning; NumBus is a log of the number of business segments; NumGeo is a log of the number of subsidiaries, FirmSize is a $\log$ of the number of company assets; FirmAge logs the number of company ages and EarnVol is the log value of volatility, and Variable control using studies [30], [75], [55], [76]. Leverage is the ratio of total debt divided by total assets; ROA is net profit of total assets multiplied by $100 \%$; BookValue is measured by the total value of equity distributed divided by the number of shares outstanding; Accruals are accruals calculated using cash flow from operations. defined as revenue before outstanding posts minus revenue from total asset scale operating activities. EarnVol is a standard deviation of revenue scaled to the total assets calculated over the last five years or, earning volatilities is the operating profit divided by the total assets. 


\subsection{Business Strategy Measurement}

A business strategy is a strategy that is located at a business-level unit created to improve the competitiveness of a company's products or services in a particular industry or market segment and used linked software development [77]. Measurement of business strategy using by [62], [78] that are: (i) Ratio of number of employees to total sales (EMPSAL), as a business strategy through efficient measurement of production and distribution capabilities of goods and services using the ratio of number of employees to total sales, (ii) The ratio of capital expenditure divided total assets (CAPTA), referred to as the intensity of fixed assets, is a comparison between capital expenditure and total assets owned by the company. (iii) Dividend payout ratio (DPR), The third business strategy uses dividend payout ratio (DPR) which is a comparison between the value of dividends per share with the profit per share (dividend per share) with earnings per share and (iv) ratio of asset utilization efficiency (UEF), looking at the efficiency of business strategy of assets, measured by the ratio of asset utilization efficiency is a comparison of total sales with total assets.

Regression Model of H2; to test business strategy on sustainable business performance, business strategy is measured from the company's financial performance, where management is able to manage the company's business, improve the competitiveness of the company's products, services and be able to compete with other companies. The $\mathrm{H} 2$ regression model is as follows:

BusSustain $_{\mathrm{i}, \mathrm{t}}=\lambda_{0}+\lambda_{1}$ EMPSAL $_{\mathrm{i}, \mathrm{t}}+\lambda_{2} \mathrm{CAPTA}_{\mathrm{i}, \mathrm{t}}+\lambda_{3} \mathrm{DPR}_{\mathrm{i}, \mathrm{t}}+\lambda_{4} \mathrm{UEF}_{\mathrm{i}, \mathrm{t}}+\lambda_{5} \mathrm{ROA}_{\mathrm{i}, \mathrm{t}}+$

$\lambda_{6}$ Leverage $_{\mathrm{i}, \mathrm{t}}+\lambda_{7}$ BookValue $_{\mathrm{i}, \mathrm{t}}+\lambda_{8}$ Accrual $_{\mathrm{i}, \mathrm{t}}+\lambda_{9}$ EarnVol $_{\mathrm{i}, \mathrm{t}}+\varepsilon_{\mathrm{i}, \mathrm{t}}$

Where: BusSustain is sustainable business performance; EMPSAL is the ratio of number of employees to total sales; CAPTA is a comparison between capital expenditure and total assets owned by the company; DPR is a comparison between the value of dividends per share with earnings per shares with earnings per share; UEF is the ratio of asset utilization efficiency is a comparison of total sales with total assets.

Regression Model of H3; Investigate and testing; complexity of business and business strategy has an impact on sustainable business performance, using the regression model as follows.

$$
\begin{aligned}
\text { BusSustain }_{\mathrm{i}, \mathrm{t}}= & \eta_{0}+\eta_{1} \text { Complexity }_{\mathrm{i}, \mathrm{t}}+\eta_{2} \text { NumBus }_{\mathrm{i}, \mathrm{t}}+\eta_{3} \text { NumGeo }_{\mathrm{i}, \mathrm{t}}+\eta_{4} \text { FirmSize }_{\mathrm{i}, \mathrm{t}}+ \\
& \eta_{5} \text { FirmAge }_{\mathrm{i}, \mathrm{t}}+\eta_{6} \text { EMPSAL }_{\mathrm{i}, \mathrm{t}}+\eta_{7} \text { CAPTA }_{\mathrm{i}, \mathrm{t}}+\eta_{8} \text { DPR }_{\mathrm{i}, \mathrm{t}}+\eta_{9} \text { UEF }_{\mathrm{i}, \mathrm{t}}+ \\
& \eta_{10} \text { ROA }_{\mathrm{i}, \mathrm{t}}+\eta_{11} \text { Leverage }_{\mathrm{i}, \mathrm{t}}+\eta_{12} \text { BookValue }_{\mathrm{i}, \mathrm{t}}+\eta_{13} \text { Accrual }_{\mathrm{i}, \mathrm{t}}+ \\
& \eta_{14} \text { EarnVol }_{\mathrm{i}, \mathrm{t}}+\varepsilon_{\mathrm{i}, \mathrm{t}}
\end{aligned}
$$




\section{Results And Discussion}

Descriptive Statistics analysis to see average values, standard deviations, maximum values and observation data used in this study. The results of processing statistical data are grouped by variables used in this study, shown in table-1 below:

Table 1: Descriptive Statistics

\begin{tabular}{lcccc}
\hline Variable & Mean & Std. Dev. & Min & Max \\
\hline Dependent Variable & & & & \\
Sustainable Business Performance: & & & & \\
$\quad$ BSustain & 0.3125 & 0.1198 & 0.0733 & 1.7425 \\
WCTA & 0.2272 & 0.1151 & 0.0919 & 1.6935 \\
RETA & 0.1980 & 0.1232 & 0.0523 & 1.2669 \\
EBITTA & 0.2104 & 0.1195 & 0.0916 & 1.4071 \\
STA & 0.2050 & 0.1144 & 0.0917 & 2.6192 \\
Independent variable: & & & & \\
Business Complexity: & & & & \\
Complexity & 0.2176 & 0.2242 & 0.0025 & 2.2688 \\
Characteristics of business complexity: & & & & \\
$\quad$ NumBus & 0.1035 & 0.1810 & 0.0012 & 0.2178 \\
NumGeo & 0.1338 & 0.7644 & 0.0006 & 0.2620 \\
FirmSize & 0.2040 & 0.2409 & 0.0007 & 5.8276 \\
FirmAge & 0.0923 & 0.1987 & 0.0136 & 1.8903 \\
Business Strategy: & & & & \\
EMPSAL & 0.0297 & 0.2842 & 0.0002 & 1.9076 \\
CAPTA & 0.2860 & 0.2795 & 0.0105 & 1.5501 \\
DPR & 0.2343 & 0.1847 & 0.0011 & 1.1056 \\
$\quad$ UEF & 0.1781 & 0.1436 & 0.0037 & 0.1299 \\
Control Variables: & & & & \\
ROA & 0.5557 & 0.2691 & 0.0043 & 0.2498 \\
Leverage & 0.4607 & 0.0846 & -0.1434 & 1.6020 \\
BookValue & 0.0194 & 0.0533 & 0.0005 & 0.1105 \\
Accruals & 0.1258 & 0.2467 & 0.0079 & 1.9786 \\
EarnVol & 0.1005 & 0.2573 & 0.0011 & 0.3328 \\
Observation & 1,215 & 1,215 & 1,215 & 1,215 \\
\hline
\end{tabular}

Table-1, shows the highest observation data is the Size variable of 5.8276, with standard deviation of 0.2409 . The highest of this data because it uses natural logarithm of total assets, while other data uses more ratio calculation, The variable that has the lowest data is Leverage with a value of -0.1434 , with a standard deviation of 0.0846 . This low data represents the low ability of companies to pay their debts from assets, or companies to address problems cash.

\subsection{Results Test of $\mathrm{H} 1$}

H1 testing; business complexity and business characteristics of the company have a negative influence on sustainable business performance (BusSustain). Testing based on industry classification i.e.; ICF-1 is a classification of raw material producing industries, 
consisting of businesses / industries in agriculture, mining, raw materials, energy; ICF-2 is a classification of manufacturing industry, consisting of basic chemical industry, various industries, consumer goods industry; ICF-3 is a classification of service industry, consisting of property \& real estate, infrastructure, utilities, transportation, finance, investment services, trade. The test results are shown in table -2 below.

Table 2: Result test of $\mathrm{H} 1$ and $\mathrm{H} 1 \mathrm{a}$, based on ICF and EVA

\begin{tabular}{|c|c|c|c|c|c|}
\hline & predict & $\begin{array}{c}\text { ICF-1 } \\
\text { BusSutain }\end{array}$ & $\begin{array}{c}\text { ICF-2 } \\
\text { BusSutain }\end{array}$ & $\begin{array}{c}\text { ICF-3 } \\
\text { BusSutain }\end{array}$ & $\begin{array}{c}\text { EVA } \\
\text { BusSutain }\end{array}$ \\
\hline \multicolumn{6}{|l|}{ Dependent Variable: } \\
\hline Complexity & - & $\begin{array}{l}0.06720 \\
(-5.88)^{* * *}\end{array}$ & $\begin{array}{l}-0.08383 \\
\quad(-9.36)^{* * *}\end{array}$ & $\begin{array}{l}-0.06844 \\
\quad(-9.07)^{* * *}\end{array}$ & $\begin{array}{l}-0.07395 \\
\quad(-3.72)^{* * *}\end{array}$ \\
\hline NumBus & + & $\begin{array}{l}0.07282 \\
\quad(3.77)^{* * *}\end{array}$ & $\begin{array}{l}0.06868 \\
\quad(7.07)^{* * *}\end{array}$ & $\begin{array}{l}0.07338 \\
\quad(7.67)^{* * *}\end{array}$ & $\begin{array}{r}0.02260 \\
\quad(0.42)\end{array}$ \\
\hline NumGeo & + & $\begin{array}{l}0.07789 \\
\quad(3.11) * * *\end{array}$ & $\begin{array}{l}0.07115 \\
\quad(57.96)^{* * * *}\end{array}$ & $\begin{array}{l}0.07868 \\
\quad(7.29) * * *\end{array}$ & $\begin{array}{r}0.03865 \\
(0.51)\end{array}$ \\
\hline FirmSize & + & $\begin{array}{l}0.06548 \\
\quad(8.60)^{* * * *}\end{array}$ & $\begin{array}{l}0.05950 \\
\quad(6.27)^{* * * *}\end{array}$ & $\begin{array}{l}0.07452 \\
\quad(10.77)^{* * *}\end{array}$ & $\begin{array}{l}0.07135 \\
\quad(3.43)^{* * *}\end{array}$ \\
\hline FirmAge & + & $\begin{array}{l}0.06308 \\
\quad(4.76)^{* * *}\end{array}$ & $\begin{array}{l}0.07130 \\
\quad(8.76)^{* * *}\end{array}$ & $\begin{array}{l}0.06796 \\
\quad(6.62)^{* * *}\end{array}$ & $\begin{array}{l}0.231997 \\
\quad(3.23)^{* * *}\end{array}$ \\
\hline \multicolumn{6}{|l|}{ Control Variables: } \\
\hline ROA & + & $\begin{array}{l}0.05424 \\
\quad(7.04)^{* * *}\end{array}$ & $\begin{array}{l}0.06738 \\
(9.69)^{* * * *}\end{array}$ & $\begin{array}{l}0.06929 \\
(12.12)^{* * *}\end{array}$ & $\begin{array}{l}0.03603 \\
\quad(1.73)^{* * * *}\end{array}$ \\
\hline Leverage & - & $\begin{array}{l}0.07734 \\
\quad(15.45) * * *\end{array}$ & $\begin{array}{l}0.07195 \\
\quad(15.72)^{* * * *}\end{array}$ & $\begin{array}{l}0.06446 \\
\quad(12.74) * * *\end{array}$ & $\begin{array}{l}0.09173 \\
\quad(3.44) * * *\end{array}$ \\
\hline BookValue & + & $\begin{array}{l}0.06905 \\
\quad(7.22) * * *\end{array}$ & $\begin{array}{l}0.06759 \\
\quad(24.73) * * *\end{array}$ & $\begin{array}{l}0.07091 \\
\quad(10.51)^{* * *}\end{array}$ & $\begin{array}{l}0.10402 \\
\quad(4.05)^{* * *}\end{array}$ \\
\hline Accruals & $?$ & $\begin{array}{l}0.06622 \\
\quad(6.42)^{* * * *}\end{array}$ & $\begin{array}{l}0.07814 \\
\quad(8.27)^{* * * *}\end{array}$ & $\begin{array}{l}0.06413 \\
\quad(9.51)^{* * * *}\end{array}$ & $\begin{array}{r}-0.04675 \\
(-1.01)\end{array}$ \\
\hline EarnVol & - & $\begin{array}{l}0.08244 \\
\quad(9.16) * * *\end{array}$ & $\begin{array}{l}0.05880 \\
\quad(7.99)^{* * * *}\end{array}$ & $\begin{array}{l}0.07280 \\
\quad(11.07)^{* * *}\end{array}$ & $\begin{array}{l}0.14694 \\
\quad(4.80)^{* * * *}\end{array}$ \\
\hline Intercept & & $\begin{array}{l}0.10793 \\
(20.43)^{* * *} \\
\end{array}$ & $\begin{array}{l}0.1048 \\
(20.13) * * *\end{array}$ & $\begin{array}{l}0.09993 \\
\quad(25.28) * * * \\
\end{array}$ & $\begin{array}{l}0.13972 \\
(8.48)^{* * * *}\end{array}$ \\
\hline Adjusted R-squared & & 0.9506 & 0.9620 & 0.8460 & 0.5436 \\
\hline Observation & & 1,215 & 1,215 & 1,215 & 1,215 \\
\hline
\end{tabular}

$t$-statistical threshold standard; $p<0.01 ; * * p<0.05 ; * p<0.10 ; \quad$ Testing based on industry classification (ICF); ICF-1 is a classification of raw material producing industries, consisting of businesses/industries in agriculture, mining, raw materials, energy; ICF-2 is a classification of manufacturing industry, consisting of basic chemical industry, various industries, consumer goods industry; ICF-3 is a classification of service industry, consisting of property \& real estate, infrastructure, utilities, transportation, finance, investment services, trading.

Table-2; test results of $\mathrm{H} 1$; Business complexity has a significant negative influence on sustainable business performance, Shown in column ICF-1, business complexity negatively affects sustainable business performance with coef $6.72 \%$; ICF-2 column business complexity has a significant negative effect on sustainable business performance with coef. $8.38 \%$ and ICF-3 business complexity have a significant negative impact on sustainable business 
performance with coef. 6,84\%. Then shown using economic value added (EVA) testing also showed the same results that business complexity has a significant negative effect on sustainable business performance with coef. 7,39\%. The three, H1 tests showed a significant negative effect, meaning that a company with complex business indicators will decrease in management performance which will in turn affect the sustainability of the business., The management and other leaders as managers of the company will face a greater responsibility to manage the company's business, duties and responsibilities, as managers and leaders, the scope of business information reports will increase. Meanwhile business demands require better performance and sustainably.

Based on Table-2, H1 indicates a company's complexity indicates that business sustainability performance will decline. Annual financial reports published on IDX were more dominant $\pm 87 \%$ in the form of letters (words and sentences) compared to the number of $\pm 13 \%$. The more complex the information presented in the financial statements is, the longer it takes to prepare and it requires a larger number of words and sentences. The more complex the disclosure of financial statements, the more likely it is that mistakes will be made, such as misstatements. If financial statements become more complicated it will increase the audit costs, and it will be more difficult to properly understand all the information reported. This will decrease the quality of the financial statements and impact the business' sustainability performance.

The results test support $\mathrm{H} 1$, that business complexity has a significant negative influence on sustainable business performance, and support the results previous study [79], [73]. Companies with large number of subsidiaries will have a high level of accounting complexity at the time of consolidation of financial statements and the complexity increases due to the complexity of the company's operations reported in financial statements, internal information and contract costs, as well as complex power and reputational risks, to support the results previous study [49], [30], [35], [50]

The result test of H1a; complexity based on business characteristics; business segments, subsidiaries, company size, has a positive influence on sustainable business performance shown in table-3. Business complexity based on company characteristics, column ICF-1 classification of raw material producing industries, consisting of businesses / industries in agriculture, mining, raw materials, energy. Business complexity based on business segment characteristics (NumBus) had a positive influence of $7.28 \%$ on sustainable business performance (BusSustain). Characteristics based on subsidiaries have a significant influence of $7.78 \%$ on sustainable business performance (BusSustain); characteristics based on company size (FirmSize) had a significant influence of $6.55 \%$ on sustainable business performance (BusSustain). The test results showed characteristics based on company age (FirmAge) also had a significant influence of $6.31 \%$. Testing in the columns ICF-2 and ICF-3 shows the same direction and results of research, namely complexity based on business characteristics of business segments, subsidiaries, company size has a positive influence on sustainable business performance. Business complexity can be controlled if each of the characteristics of business complexity (business segment performance report, subsidiary report) is reported separately, and not combined in the consolidated report. Each segment and its subsidiaries will more easily implement management control systems and have a positive influence on sustainable business performance. Overall H1a test results support the hypothesis (H1a) in this study. 
Table 3. Result test of $\mathrm{H} 1$ and $\mathrm{H} 1 \mathrm{a}$ based on sustainable business performance characteristics

\begin{tabular}{|c|c|c|c|c|c|}
\hline & $\mathrm{d}$ & $\begin{array}{c}\text { WCA } \\
\text { BusSutaint }\end{array}$ & $\begin{array}{c}\text { RETA } \\
\text { BusSutain }\end{array}$ & $\begin{array}{c}\text { EBITTA } \\
\text { BusSutain }\end{array}$ & $\begin{array}{c}\text { STA } \\
\text { BusSutain }\end{array}$ \\
\hline \multicolumn{6}{|l|}{ Dependent Variable } \\
\hline Complexity & & $\begin{array}{l}-0.07546 \\
(-14.29)^{* * *}\end{array}$ & $\begin{array}{l}-0.08126 \\
(-14.29)^{* * * *}\end{array}$ & $\begin{array}{l}-0.08803 \\
\quad(-14.29) * * *\end{array}$ & $\begin{array}{l}-0.09603 \\
(-14.29)^{* * * *}\end{array}$ \\
\hline NumBus & + & $\begin{array}{l}0.06696 \\
\quad(9.90)^{* * * *}\end{array}$ & $\begin{array}{l}0.07211 \\
\quad(9.90) * * *\end{array}$ & $\begin{array}{l}0.07812 \\
\quad(9.90) * * *\end{array}$ & $\begin{array}{l}0.08522 \\
(9.90) * * *\end{array}$ \\
\hline NumGeo & + & $\begin{array}{l}0.07129 \\
(48.09) * * *\end{array}$ & $\begin{array}{l}0.07677 \\
(48.09) * * *\end{array}$ & $\begin{array}{l}0.08317 \\
\quad(48.09) * * *\end{array}$ & $\begin{array}{l}0.09073 \\
(48.09)^{* * * *}\end{array}$ \\
\hline FirmSize & + & $\begin{array}{l}0.07013 \\
\quad(14.33)^{* * * *}\end{array}$ & $\begin{array}{l}0.07552 \\
\quad(14.33)^{* * *}\end{array}$ & $\begin{array}{l}0.08182 \\
\quad(14.33) * * *\end{array}$ & $\begin{array}{l}0.08925 \\
(14.33)^{* * *}\end{array}$ \\
\hline FirmAge & + & $\begin{array}{l}0.06929 \\
(10.93)^{* * *}\end{array}$ & $\begin{array}{l}0.07462 \\
\quad(10.93) * * *\end{array}$ & $\begin{array}{l}0.08085 \\
\quad(10.93)^{* * * *}\end{array}$ & $\begin{array}{l}0.08819 \\
\quad(10.93) * * *\end{array}$ \\
\hline \multicolumn{6}{|l|}{ Control Variables. } \\
\hline ROA & + & $\begin{array}{l}0.06234 \\
(14.77)^{* * * *}\end{array}$ & $\begin{array}{l}-0.00978 \\
(-2.15)^{* *}\end{array}$ & $\begin{array}{l}-0.01059 \\
(-2.15)^{* *}\end{array}$ & $\begin{array}{r}-0.01156 \\
(-2.15)\end{array}$ \\
\hline Leve & - & $\begin{array}{l}0.07010 \\
\quad(21.67)^{* * * *}\end{array}$ & $\begin{array}{l}0.07549 \\
\quad(21.67)^{* * * *}\end{array}$ & $\begin{array}{r}-0.00155 \\
(-0.41)\end{array}$ & $\begin{array}{r}-0.00169 \\
(-0.41)\end{array}$ \\
\hline BookValue & + & $\begin{array}{l}0.07061 \\
\quad(25.34) * * *\end{array}$ & $\begin{array}{l}0.07604 \\
\quad(25.34) * * *\end{array}$ & $\begin{array}{l}0.08238 \\
\quad(25.34)^{* * * *}\end{array}$ & $\begin{array}{l}-0.00103 \\
(-0.29)^{*} * *\end{array}$ \\
\hline Accruals & $?$ & $\begin{array}{l}0.06380 \\
\quad(12.15)^{* * *}\end{array}$ & $\begin{array}{l}0.06871 \\
\quad(12.15)^{* * *}\end{array}$ & $\begin{array}{l}0.07444 \\
\quad(12.15)^{* * * *}\end{array}$ & $\begin{array}{l}0.08120 \\
\quad(12.15)^{* * * *}\end{array}$ \\
\hline EarnVol & - & $\begin{array}{l}0.07631 \\
\quad(15.91)^{* * *}\end{array}$ & $\begin{array}{l}0.08218 \\
\quad(15.91)^{* * *}\end{array}$ & $\begin{array}{l}0.08904 \\
\quad(15.91)^{* * *}\end{array}$ & $\begin{array}{l}0.09713 \\
(15.91)^{* * * *}\end{array}$ \\
\hline Intercept & & $\begin{array}{l}0.10776 \\
(36.20)^{* * *}\end{array}$ & $\begin{array}{l}0.11220 \\
\quad(35.00)^{* * *}\end{array}$ & $\begin{array}{l}0.11739 \\
\quad(33.80)^{* * * *}\end{array}$ & $\begin{array}{l}0.12352 \\
(32.60)^{* * * *}\end{array}$ \\
\hline & & 0.8850 & 0.8835 & 0.8547 & 0.8113 \\
\hline Data Observations & & 1,215 & 1,215 & 1,215 & 1,215 \\
\hline
\end{tabular}

$t$-statistical threshold standard; $p<0.01 ; * * p<0.05 ; * p<0.10 ; p<0.01 ; * * p<0.05 ; * p<0.10 ;$ Next test based on financial institutions data, such as: WCTA is a ratio measuring the ability of companies to meet short-term liabilities, RETA is a comparison of retained earnings with total assets. EBITTA is the ratio of measuring the ability of a company to generate profit from the assets used, EBIT is the ratio of detecting the ability of a company's funds embedded in the overall assets that rotate in a given period.

Table-3, H1 and H1a testing show the same direction and significance as the previous tests in Table-3. H1 statistical test results show that business complexity has a significant negative influence on sustainable business performance. These results tend to be due to top level management and other leaders who manage a company not having adequate knowledge to be able to manage large, complex businesses. If the company does not have the ability or lack of knowledge on the complexity of the business, then the company will and there will be a decrease in the sustainable of business performance, statistically the results of this test support the research hypothesis.

The results of H1a testing in Table 3, also show that business complexity based on business characteristics of business segments; subsidiaries, company size has a positive influence on sustainable business performance. This means that reducing the complexity of a company's business can be through the implementation of an internal control system that focuses on each unit of business segment activities and each subsidiary. A management control system based on financial performance results is an appropriate model applied to each 
business activity unit, so that the presentation of performance information and reports are more accurate and the scope of information is more controlled by each business activity unit. Overall, the test results support the H1a hypothesis of this study.

Table 4: Panel A. Result test of H2; business strategy on sustainable business performance

\begin{tabular}{|c|c|c|c|c|c|}
\hline & Predicts & $\begin{array}{c}\text { ICF-1 } \\
\text { BusSutain }\end{array}$ & $\begin{array}{c}\text { ICF-2 } \\
\text { BusSutain }\end{array}$ & $\begin{array}{c}\text { ICF-3 } \\
\text { BusSutain }\end{array}$ & $\begin{array}{c}\text { EVA } \\
\text { BusSutain }\end{array}$ \\
\hline \multicolumn{6}{|l|}{ Dependent Variable } \\
\hline \multicolumn{6}{|l|}{ Business Strategies: } \\
\hline EMPSAL & + & $\begin{array}{l}0.79126 \\
\quad(2.90) * * *\end{array}$ & $\begin{array}{l}0.87031 \\
\quad(0.98) * * *\end{array}$ & $\begin{array}{l}0.07503 \\
\quad(15.72) * * *\end{array}$ & $\begin{array}{l}0.04794 \\
\quad(4.29) * * *\end{array}$ \\
\hline CAPTA & + & $\begin{array}{l}0.08364 \\
\quad(9.15)^{* * * *}\end{array}$ & $\begin{array}{l}0.24408 \\
\quad(1.67)^{* * * *}\end{array}$ & $\begin{array}{l}0.06531 \\
\quad(2.98)^{* * * *}\end{array}$ & $\begin{array}{r}0.048461 \\
(0.95)\end{array}$ \\
\hline DPR & + & $\begin{array}{l}0.08352 \\
\quad(9.45) * * *\end{array}$ & $\begin{array}{l}0.11747 \\
\quad(2.90)^{* * *}\end{array}$ & $\begin{array}{l}0.06775 \\
\quad(8.41)^{* * * *}\end{array}$ & $\begin{array}{l}0.05021 \\
(2.66) * * *\end{array}$ \\
\hline AUF & + & $\begin{array}{r}0.02851 \\
\quad(1.31)\end{array}$ & $\begin{array}{r}-0.24445 \\
(-1.00)\end{array}$ & $\begin{array}{l}0.07302 \\
\quad(2.23)^{* * *}\end{array}$ & $\begin{array}{l}0.23782 \\
\quad(3.10)^{* * * *}\end{array}$ \\
\hline \multicolumn{6}{|l|}{ Control Variables: } \\
\hline $\mathrm{ROA}$ & + & $\begin{array}{l}0.07488 \\
(10.69)^{* * *}\end{array}$ & $\begin{array}{l}0.09940 \\
(3.82)^{* * *}\end{array}$ & $\begin{array}{r}0.06845 \\
(13.02)\end{array}$ & $\begin{array}{r}0.04967 \\
(4.04)\end{array}$ \\
\hline Leverage & - & $\begin{array}{l}0.10021 \\
\quad(20.61)^{* * *}\end{array}$ & $\begin{array}{l}0.12217 \\
\quad(7.62) * * *\end{array}$ & $\begin{array}{l}0.09032 \\
(19.55) * * *\end{array}$ & $\begin{array}{l}0.08291 \\
(7.79) * * *\end{array}$ \\
\hline BookValue & + & $\begin{array}{l}0.09610 \\
\quad(11.40)^{* * *}\end{array}$ & $\begin{array}{l}0.07680 \\
\quad(8.33) * * *\end{array}$ & $\begin{array}{l}0.12803 \\
\quad(22.05)^{* * * *}\end{array}$ & $\begin{array}{l}0.09072 \\
\quad(6.72)^{* * * *}\end{array}$ \\
\hline Accruals & $?$ & $\begin{array}{l}0.12078 \\
\quad(12.54) * * *\end{array}$ & $\begin{array}{l}0.10053 \\
\quad(3.01) * * *\end{array}$ & $\begin{array}{l}0.10701 \\
\quad(17.49) * * *\end{array}$ & $\begin{array}{l}0.111696 \\
\quad(7.97)^{* * * *}\end{array}$ \\
\hline EarnVol & - & $\begin{array}{l}0.05896 \\
(6.77) * * *\end{array}$ & $\begin{array}{l}0.093112 \\
(3.39)^{* * * *}\end{array}$ & $\begin{array}{l}0.09543 \\
\quad(15.94) * * *\end{array}$ & $\begin{array}{l}0.11283 \\
\quad(11.22)^{* * * *}\end{array}$ \\
\hline Intercept & $?$ & $\begin{array}{l}0.07939 \\
(11.46) * * *\end{array}$ & $\begin{array}{l}0.06675 \\
(2.49) * * *\end{array}$ & $\begin{array}{l}0.08775 \\
(19.44)^{* * *}\end{array}$ & $\begin{array}{l}0.21124 \\
(20.00) * * *\end{array}$ \\
\hline F- Test Statistic & & 0.0000 & 0.0000 & 0.0000 & 0.0000 \\
\hline Adjusted R-squared & & 0.9017 & 0.4650 & 0.8668 & 0.4057 \\
\hline Observation & & 1,215 & 1,215 & 1,215 & 1,215 \\
\hline
\end{tabular}

Table 4, Panel A, shows the $\mathrm{H} 2$ test results; that business strategy has a positive influence on sustainable business performance. The results of the first business strategy test use EMPSAL. The ICF-1 column shows that business strategy with EMPSAL proxy has a significant positive influence of $79.12 \%$ on sustainable business performance; ICF-2 column of business strategy has a significant positive influence of $87.03 \%$ on sustainable business performance; ICF-3 column of business strategy has a significant positive influence of $7.50 \%$ on sustainable business performance. The EMPSAL business strategy proves that companies with a large number of employees have successfully innovated superior products in the market are able to compete with competitors and the system has been well formed so that the increase of new employees able to maintain sustainable business performance. Companies that have a high EMPSAL value are indicated by prospector technology companies. Prospector companies have a greater intensity in the process of creating new products, the ability to create higher margins and profit growth. This opinion is quite reasonable because new products 
produced by the company have not had a rival in the short term and as a business strategy for the long term, so that the product can be sold at a higher price. The conclusion is that business strategy has a positive influence on sustainable business performance. The better the implementation of business strategy, the more sustainable business performance will be. All three proxy test results support the hypothesis of this study.

The second $\mathrm{H} 2$ test; the results business strategy test use capital expenditure (CAPTA) to analyze whether the business strategy of a company's ability to achieve annual capital expenditure running of total assets for the current year sustainable. Test result Table 4, panel A; test results of column ICF-1; business strategy has a significant positive influence of $8.36 \%$ on sustainable business performance; ICF-2 column; business strategy has a significant positive influence of $24.40 \%$ on sustainable business performance; ICF-3 column; business strategy has a significant positive influence of $6.53 \%$ on sustainable business performance.

The third $\mathrm{H} 2$ test in Table 4, panel A; business strategy test used proxy dividend payout ratio (DPR) to analyze the business strategy based on the comparison between the dividend value of shares and the share earnings. Test results; ICF-1 column; business strategy using DPR has a significant positive influence of $8.35 \%$ on sustainable business performance; ICF-2 column; business strategy using DPR has a significant positive influence of $11.74 \%$ on sustainable business performance and ICF-3 column; Business strategy using DPR has a significant positive influence of $6.77 \%$ on sustainable business performance. The measurement of business strategy with DPR shows the ability of the company to pay dividends to investors. The company pays dividends on time every year, showing managers and other leaders have provided good performance, and the company is certain to experience an increase in profit. The higher the value of DPR ratio, the better the sustainable business performance will be.

The fourth $\mathrm{H} 2$ testing; business strategy test uses proxy asset utilization efficiency (AUF), to assess whether the business strategy used by the manager increases the asset value or the achievement of asset value by comparing the total sales with total assets. Test results Table-4 Panel A; ICF-1 column; business strategy using AUF has a significant positive influence of $2.85 \%$ on sustainable business performance; ICF-2 column; business strategy using AUF has a significant negative influence of $-24.44 \%$ on sustainable business performance and ICF-3 column; Business strategy using AUF has a significant positive influence of $7.30 \%$ on sustainable business performance.

Measurement of business strategy using AUF, demonstrates a company's ability to increase the value of assets from sales. Overall $\mathrm{H} 2$ testing of business strategies using AUF proxies, suggest that managers and other management leaders should have the ability to increase asset value or achieve asset value gained from total sales. Business strategy using AUF measurements show test results that business strategy has a positive influence on sustainable business performance. The test results use a proxy UEF ratio, indicating the business strategy has an influence on sustainable business performance. The results support the research hypothesis.

Further testing to prove the results of $\mathrm{H} 2$ in Table 4, panel A. Test results of the effect of business strategy on sustainable business performance with EVA measurement; (1) EMPSAL has a significant positive effect of $4.79 \%$ on sustainable business performance with EVA measurement. (2) CAPTA had a significant positive impact of $4.84 \%$ on sustainable 
business performance with EVA measurement. (3) The House of Representatives has a significant positive effect of $5.02 \%$ on sustainable business performance with EVA measurement. AUF had a significant positive impact of $23.78 \%$ on sustainable business performance with EVA measurement. Overall, business strategies have a positive impact on sustainable business performance. EVA as a measure of the company's performance shows management efficiency in turning investor capital into profit, namely creating economic value. EVA created a scheme that incorporates capital costs in performance evaluation, so that performance achievements turn investor capital into profit. This is one of the main foundations of management in a company to improve performance so that the company's performance remains sustainable in carrying out operational business activities.

Table 4; Panel B. results test of business strategy and sustainable business performance

\begin{tabular}{|c|c|c|c|c|c|}
\hline & Predict & $\begin{array}{c}\text { WCA } \\
\text { BusSutaint }\end{array}$ & $\begin{array}{c}\text { RETA } \\
\text { BusSutain }\end{array}$ & $\begin{array}{c}\text { EBITTA } \\
\text { BusSutain }\end{array}$ & $\begin{array}{c}\text { STA } \\
\text { BusSutain }\end{array}$ \\
\hline \multicolumn{6}{|l|}{ Dependent Variable } \\
\hline EMPSAL & + & $\begin{array}{l}0.07826 \\
(10.88) * * *\end{array}$ & $\begin{array}{l}0.08428 \\
\quad(10.88)^{* * * *}\end{array}$ & $\begin{array}{l}0.091314 \\
\quad(10.88)^{* * * *}\end{array}$ & $\begin{array}{l}0.09961 \\
\quad(10.88) * * *\end{array}$ \\
\hline CAPTA & + & $\begin{array}{l}0.07679 \\
\quad(4.99) * * *\end{array}$ & $\begin{array}{l}0.082703 \\
\quad(4.99) * * *\end{array}$ & $\begin{array}{l}0.08959 \\
(4.99)^{* * *}\end{array}$ & $\begin{array}{l}0.09774 \\
\quad(4.99) * * *\end{array}$ \\
\hline DPR & + & $\begin{array}{l}0.08376 \\
\quad(8.28)^{* * * *}\end{array}$ & $\begin{array}{l}0.09021 \\
\quad(8.28)^{* * * *}\end{array}$ & $\begin{array}{l}0.09772 \\
\quad(8.28) * * *\end{array}$ & $\begin{array}{l}0.10661 \\
(8.28)^{* * *}\end{array}$ \\
\hline AUF & + & $\begin{array}{r}0.04241 \\
(1.39)\end{array}$ & $\begin{array}{r}0.04567 \\
(1.39)\end{array}$ & $\begin{array}{l}0.04948 \\
\quad(1.39)^{* * * *}\end{array}$ & $\begin{array}{l}0.05398 \\
\quad(1.39)^{* * *}\end{array}$ \\
\hline \multicolumn{6}{|l|}{ Control Variables: } \\
\hline ROA & + & $\begin{array}{l}0.07972 \\
(11.37)^{* * *}\end{array}$ & $\begin{array}{l}0.00893 \\
(1.18)^{* * *}\end{array}$ & $\begin{array}{r}0.00967 \\
(1.18)\end{array}$ & $\begin{array}{r}0.01056 \\
(1.18)\end{array}$ \\
\hline Leverage & - & $\begin{array}{l}0.10618 \\
\quad(20.55)^{* * * *}\end{array}$ & $\begin{array}{l}0.11435 \\
\quad(20.55)^{* * * *}\end{array}$ & $\begin{array}{l}0.04055 \\
\quad(6.73)^{* * * *}\end{array}$ & $\begin{array}{l}0.044238 \\
(6.73)^{* * *}\end{array}$ \\
\hline Book Value & + & $\begin{array}{l}0.08686 \\
\quad(19.77)^{* * * *}\end{array}$ & $\begin{array}{l}0.09354 \\
\quad(19.77)^{* * * *}\end{array}$ & $\begin{array}{l}0.10134 \\
\quad(19.77) * * *\end{array}$ & $\begin{array}{l}0.019643 \\
(3.51)^{* * * *}\end{array}$ \\
\hline Accruals & $?$ & $\begin{array}{l}0.11635 \\
\quad(13.89)^{* * * *}\end{array}$ & $\begin{array}{l}0.12530 \\
\quad(13.89) * * *\end{array}$ & $\begin{array}{l}0.13574 \\
\quad(13.89)^{* * * *}\end{array}$ & $\begin{array}{l}0.14808 \\
(13.89) * * *\end{array}$ \\
\hline EarnVol & - & $\begin{array}{l}0.08865 \\
\quad(11.22)^{* * * *}\end{array}$ & $\begin{array}{l}0.09548 \\
\quad(11.22)^{* * * *}\end{array}$ & $\begin{array}{l}0.10343 \\
\quad(11.22)^{* * * *}\end{array}$ & $\begin{array}{l}0.11283 \\
\quad(11.22)^{* * * *}\end{array}$ \\
\hline Intercept & $?$ & $\begin{array}{l}0.08881 \\
\quad(15.56)^{* * *}\end{array}$ & $\begin{array}{l}0.09179 \\
(14.93) * * *\end{array}$ & $\begin{array}{l}0.09528 \\
\quad(14.31)^{* * * *}\end{array}$ & $\begin{array}{l}0.09939 \\
(13.68) * * *\end{array}$ \\
\hline F- Test Statistic & & 0.0000 & 0.0000 & 0.0000 & 0.0000 \\
\hline Adjusted R-squared & & 0.6818 & 0.8835 & 0.8547 & 0.8113 \\
\hline Data Observation & & 1,215 & 1,215 & 1,215 & 1,215 \\
\hline
\end{tabular}

$t$-statistical threshold standard; $* * * p<0,01 ; * * p<0,05 ; * p<0,10$. Sustainable business performance using four approaches; (i) measurement using working capital to total assets (WCTA); (ii) measurement using retained earning to total assets ratio (RETA); (iii) measurement using earnings before interest and tax to total assets ratio (EBITTA); (iv) measurement using sales to total assets ratio (STA).

Table-4, Panel B supports the results of $\mathrm{H} 2$ test; business strategy has a positive influence on sustainable business performance. (1) WCA columns; that business strategies with EMPSAL, CAPTA, DPR and AUF approaches have a significant and positive influence on sustainable business performance measurement using working capital to total assets 
(WCA) simultaneously based on Adjusted R-squared by 68.18\%; based on business strategy, the company has the ability to meet short-term obligations. (2) RETA; business strategies with EMPSAL, CAPTA, DPR and AUF approaches have a significant and positive influence on sustainable business performance measurement using retained earnings to total assets ratio (RETA), simultaneously based on Adjusted R-squared of 88.35\%; business strategies based on financial performance show managers have the ability to increase the profit from the use of assets. (3) in column EBITTA; business strategies with EMPSAL, CAPTA, DPR and AUF approaches have a significant and positive influence on sustainable business performance measurement using earnings before interest and tax to total assets ratio (EBITTA) simultaneously based on adjusted r-squared effect of $85.47 \%$; a company's management is able to generate profit from the assets used, where the company's profit is revenue obtained from the company's operational activities. (4) STA column; that business strategies with EMPSAL, CAPTA, DPR and AUF approaches have a significant and positive influence on sustainable business performance measurement using sales to total assets ratio (STA), simultaneously based on adjusted r-squared influence of $81.13 \%$; STA to detect the measurement of financial performance of the manager's ability to escape the company's funds from the turnover of assets in one accounting period. Overall that $\mathrm{H} 2$ testing; Business strategies have a positive influence on sustainable business performance and the test results support the $\mathrm{H} 2$ hypothesis of this study.

Table 5. Result test of H3; business complexity, business characteristics and business strategy on sustainable business performance

\begin{tabular}{|c|c|c|c|}
\hline & predict & & BusSutain \\
\hline \multicolumn{4}{|c|}{ Independent variable: } \\
\hline Complexity & - & -0.052639 & $(-4.98) * * *$ \\
\hline \multicolumn{4}{|c|}{ Characteristic Business: } \\
\hline NumBus & + & 0.066195 & $(4.89)^{* * *}$ \\
\hline NumGeo & + & 0.053819 & $(18.16)^{* * *}$ \\
\hline FirmSize & + & 0.095441 & $(9.70)^{* * *}$ \\
\hline FirmAge & + & 0.046259 & $(3.65)^{* * *}$ \\
\hline \multicolumn{4}{|l|}{ Business strategies: } \\
\hline EMPSAL & + & 0.063389 & $(7.30)^{* * *}$ \\
\hline CAPTA & + & 0.068695 & $(3.70)^{* * *}$ \\
\hline DPR & + & 0.058151 & $(4.78)^{* * *}$ \\
\hline UEF & + & 0.034393 & $(0.94)$ \\
\hline \multicolumn{4}{|l|}{ Control Variables: } \\
\hline ROA & + & 0.054916 & $(6.48)^{* * *}$ \\
\hline Leverage & - & 0.043498 & $(6.73)^{* * *}$ \\
\hline BookValue & + & 0.054817 & $(9.84)^{* * *}$ \\
\hline Accruals & - & 0.058731 & $(5.58)^{* * *}$ \\
\hline EarnVol & + & 0.057389 & $(5.96)^{* * *}$ \\
\hline Intercept & & 0.166259 & $(22.60) * * *$ \\
\hline Prob $>$ F & & 0.0000 & \\
\hline Adjusted R-squared & & 0.5807 & \\
\hline Observation & & 1,215 & \\
\hline
\end{tabular}




\section{Conclusion}

Business complexity is the breadth of business activities managed by leaders, both managers and director, Therefore, information that reports management performance should be broader. Companies that certainly face a variety of challenges such as reporting standards, regulations and work systems, investor demands, business market demands and the possibility of business reporting errors, thus requiring a more comprehensive investigation. Business complexity affects the company's performance and has a negative impact on sustainable business performance. This is a challenge for managers, leaders including the board of directors and CEOs to continuously improve the corporation based on management performance in the short and long term. Performance can be measured based on non-financial performance and financial performance as economic performance. The results of test showed that business complexity has a significant negative influence on sustainable business performance, Complexity reflected has many business problems at managers and reduced management performance had impacts to sustainable business performance. Next for business strategy has a significant positive influence on sustainable business performance.

Future research needs to explore problems from business complexity to unique problems faced by company managers, as a major trend must be managed with a sustainable business strategy that uses data between countries. Sustainable business performance has been a constant debate in literature studies over the past few decades. However, business complexity and business strategy can use financial performance data generated by companies to measure companies performance in maintaining sustainable business.

\section{Acknowledgment}

We would like to thank the head of graduate study in accounting science programs at Universitas Indonesia whom has given directions to obtain research data, We would also like to thank Mrs. Lindawati Gani and Hilda Rossieta for their constructive comments and suggestions that considerably improved the quality of this paper.

\section{References}

[1] P. M. Dechow and S. Douglas J, "Reproduced with permission of the copyright owner . Further reproduction prohibited without," J. Allergy Clin. Immunol., vol. 130, no. 2, p. 556, 2000, [Online]. Available: http://dx.doi.org/10.1016/j.jaci.2012.05.050.

[2] R. A. Lambert, "Customer Satisfaction and Future Financial Performance Discussion of are Nonfinancial Measures Leading Indicators of Financial Performance? An Analysis of Customer Satisfaction," J. Account. Res., vol. 36, p. 37, 1998, doi: $10.2307 / 2491305$.

[3] Salameh, Alzyada, and Ahmad, "Implementation of (TQM) in the Faculty of Planning \& Management at Al-Balqa Applied University," Int. J. Bus. Manag., vol. 6, no. 3, pp. 194-207, 2011, doi: 10.5539/ijbm.v6n3p194.

[4] J. B. McGuire, A. Sundgren, and T. Schneeweis, "Corporate Social Responsibility and Firm Financial Performance,” Acad. Manag. J., vol. 31, no. 4, pp. 854-872, 1988, doi: $10.5465 / 256342$.

[5] K. Ahmad and S. M. Zabri, "The Application of Non-Financial Performance Measurement in Malaysian Manufacturing Firms," Procedia Econ. Financ., vol. 35, no. October 2015, pp. 476-484, 2016, doi: 10.1016/S2212-5671(16)00059-9. 
[6] M. Mohaghegh, S. Blasi, and A. Größler, "Dynamic capabilities linking lean practices and sustainable business performance," J. Clean. Prod., vol. 322, no. September, 2021, doi: 10.1016/j.jclepro.2021.129073.

[7] M. Geissdoerfer, D. Vladimirova, and S. Evans, "Sustainable business model innovation: A review," J. Clean. Prod., vol. 198, pp. 401-416, Oct. 2018, doi: 10.1016/j.jclepro.2018.06.240.

[8] V. A. Refmasari and R. A. Supriyono, "Effect of Non-Financial Performance towards Financial Performance Moderated by Information Disclosure," J. Econ. Bus. Account. Ventur., vol. 22, no. 2, 2019, doi: 10.14414/jebav.v22i2.1694.

[9] Lăzăroiu, et all., "Lăzăroiu 2020.pdf," Sustainability, vol. 12, no. Sustainability Management and Performance in the Urban Corporate Economy: A Systematic Literature Review, 2020.

[10] D. Alonso-Martinez, V. De Marchi, and E. Di Maria, "The sustainability performances of sustainable business models," J. Clean. Prod., vol. 323, no. January, p. 129145, Nov. 2021, doi: 10.1016/j.jclepro.2021.129145.

[11] S. Du, L. Bstieler, and G. Yalcinkaya, "Sustainability-focused innovation in the business-to-business context: Antecedents and managerial implications," J. Bus. Res., vol. 138, no. September 2021, pp. 117-129, Jan. 2022, doi: 10.1016/j.jbusres.2021.09.006.

[12] M. S. Chiucchi, "Editoriale. Il gap tra teoria e prassi nel Management Accounting: il contributo della field-based research," Manag. Control, no. 3, pp. 5-9, Jan. 2015, doi: 10.3280/MACO2014-003001.

[13] D. McKenzie and C. Woodruff, "Business Practices in Small Firms in Developing Countries," Manage. Sci., vol. 63, no. 9, pp. 2967-2981, Sep. 2017, doi: 10.1287/mnsc.2016.2492.

[14] S. Evans et al., "Business Model Innovation for Sustainability: Towards a Unified Perspective for Creation of Sustainable Business Models," Bus. Strateg. Environ., vol. 26, no. 5, pp. 597-608, Jul. 2017, doi: 10.1002/bse.1939.

[15] H. Maheswari, G. Yudoko, A. Adhiutama, and H. Agustina, "Sustainable reverse logistics scorecards for the performance measurement of informal e-waste businesses," Heliyon, vol. 6, no. 9, p. e04834, Sep. 2020, doi: 10.1016/j.heliyon.2020.e04834.

[16] A. Klettner, T. Clarke, and M. Boersma, "The Governance of Corporate Sustainability: Empirical Insights into the Development, Leadership and Implementation of Responsible Business Strategy," J. Bus. Ethics, vol. 122, no. 1, pp. 145-165, Jun. 2014, doi: 10.1007/s10551-013-1750-y.

[17] F. Boons and F. Lüdeke-Freund, "Business models for sustainable innovation: state-ofthe-art and steps towards a research agenda," J. Clean. Prod., vol. 45, pp. 9-19, Apr. 2013, doi: 10.1016/j.jclepro.2012.07.007.

[18] R. Lamboglia, R. Fiorentino, D. Mancini, and S. Garzella, "From a garbage crisis to sustainability strategies: The case study of Naples' waste collection firm," J. Clean. Prod., vol. 186, pp. 726-735, Jun. 2018, doi: 10.1016/j.jclepro.2018.03.151.

[19] R. J. Baumgartner and D. Ebner, "Corporate sustainability strategies: sustainability profiles and maturity levels," Sustain. Dev., vol. 18, no. 2, pp. 76-89, Mar. 2010, doi: 10.1002/sd.447.

[20] N. B. Kurland and D. Zell, "Water and Business: A Taxonomy and Review of the Research," Organ. Environ., vol. 23, no. 3, pp. 316-353, Sep. 2010, doi: $10.1177 / 1086026610382627$.

[21] Thomas B. Long, Decent Work and Economic Growth, no. June. Cham: Springer 
International Publishing, 2020.

[22] M. Beckmann, S. Hielscher, and I. Pies, "Commitment Strategies for Sustainability: How Business Firms Can Transform Trade-Offs Into Win-Win Outcomes," Bus. Strateg. Environ., vol. 23, no. 1, pp. 18-37, Jan. 2014, doi: 10.1002/bse.1758.

[23] A. C. Ng and Z. Rezaee, "Business sustainability performance and cost of equity capital," J. Corp. Financ., vol. 34, pp. 128-149, Oct. 2015, doi: 10.1016/j.jcorpfin.2015.08.003.

[24] M. K. Shad, F.-W. Lai, C. L. Fatt, J. J. Klemeš, and A. Bokhari, "Integrating sustainability reporting into enterprise risk management and its relationship with business performance: A conceptual framework," J. Clean. Prod., vol. 208, pp. 415425, Jan. 2019, doi: 10.1016/j.jclepro.2018.10.120.

[25] L. Alinaghian and K. Razmdoost, "How do social enterprises manage business relationships? A review of the literature and directions for future research," J. Bus. Res., vol. 136, no. August, pp. 488-498, Nov. 2021, doi: 10.1016/j.jbusres.2021.08.003.

[26] M. Jankalová and J. Kurotová, "Sustainability Assessment Using Economic Value Added," Sustainability, vol. 12, no. 1, p. 318, Dec. 2019, doi: 10.3390/su12010318.

[27] M. Subedi and A. Farazmand, "Economic Value Added (EVA) for Performance Evaluation of Public Organizations," Public Organ. Rev., vol. 20, no. 4, pp. 613-630, Dec. 2020, doi: 10.1007/s11115-020-00493-2.

[28] E. Kassem, O. Trenz, J. Hřebíček, and O. Faldík, "Sustainability Assessment Using Sustainable Value Added," Procedia - Soc. Behav. Sci., vol. 220, pp. 177-183, May 2016, doi: 10.1016/j.sbspro.2016.05.482.

[29] A. Ekici and Ş. Önsel Ekici, "Understanding and managing complexity through Bayesian network approach: The case of bribery in business transactions," J. Bus. Res., vol. 129, no. March 2019, pp. 757-773, May 2021, doi: 10.1016/j.jbusres.2019.10.024.

[30] W. Guay, D. Samuels, and D. Taylor, "Guiding through the Fog: Financial statement complexity and voluntary disclosure," J. Account. Econ., vol. 62, no. 2-3, pp. 234-269, Nov. 2016, doi: 10.1016/j.jacceco.2016.09.001.

[31] R. Rodríguez, F.-J. Molina-Castillo, and G. Svensson, "The mediating role of organizational complexity between enterprise resource planning and business model innovation," Ind. Mark. Manag., vol. 84, no. September 2019, pp. 328-341, Jan. 2020, doi: 10.1016/j.indmarman.2019.09.007.

[32] C. Konrad, G. Jacobs, R. Rasor, R. Riedel, T. Katzwinkel, and J. Siebrecht, "Enabling complexity management through merging business process modeling with MBSE," Procedia CIRP, vol. 84, pp. 451-456, 2019, doi: 10.1016/j.procir.2019.04.267.

[33] A. Chernobai, A. Ozdagli, and J. Wang, "Business complexity and risk management: Evidence from operational risk events in U.S. bank holding companies," J. Monet. Econ., vol. 117, pp. 418-440, Jan. 2021, doi: 10.1016/j.jmoneco.2020.02.004.

[34] Y. Yang, Q. Liu, J. Song, and M. Zhou, "The influence mechanism of financial shared service mode on the competitive advantage of enterprises from the perspective of organizational complexity: A force field analysis," Int. J. Account. Inf. Syst., vol. 42, no. March, p. 100525, Sep. 2021, doi: 10.1016/j.accinf.2021.100525.

[35] T. Dyer, M. Lang, and L. Stice-Lawrence, "The evolution of 10-K textual disclosure: Evidence from Latent Dirichlet Allocation," J. Account. Econ., vol. 64, no. 2-3, pp. 221-245, Nov. 2017, doi: 10.1016/j.jacceco.2017.07.002.

[36] J. Ukko, M. Nasiri, M. Saunila, and T. Rantala, "Sustainability strategy as a moderator in the relationship between digital business strategy and financial performance," $J$. 
Clean. Prod., vol. 236, p. 117626, Nov. 2019, doi: 10.1016/j.jclepro.2019.117626.

[37] N. M. P. Bocken, S. W. Short, P. Rana, and S. Evans, "A literature and practice review to develop sustainable business model archetypes," J. Clean. Prod., vol. 65, no. September, pp. 42-56, Feb. 2014, doi: 10.1016/j.jclepro.2013.11.039.

[38] R. Ameer and R. Othman, "Sustainability Practices and Corporate Financial Performance: A Study Based on the Top Global Corporations," J. Bus. Ethics, vol. 108, no. 1, pp. 61-79, Jun. 2012, doi: 10.1007/s10551-011-1063-y.

[39] J. de Nadae and M. M. de Carvalho, "Integrated management systems as a driver for sustainability: the review and analysis of the literature and the proposition of the conceptual framework," Production, vol. 29, 2019, doi: 10.1590/0103-6513.20180048.

[40] A. Alshehhi, H. Nobanee, and N. Khare, "The Impact of Sustainability Practices on Corporate Financial Performance: Literature Trends and Future Research Potential," Sustainability, vol. 10, no. 2, p. 494, Feb. 2018, doi: 10.3390/su10020494.

[41] N. C. Shil, "Performance Measures: An Application of Economic Value Added," Int. J. Bus. Manag., vol. 4, no. 3, Feb. 2009, doi: 10.5539/ijbm.v4n3p169.

[42] N. Altaf, "Economic value added or earnings: What explains market value in Indian firms?," Futur. Bus. J., vol. 2, no. 2, pp. 152-166, Dec. 2016, doi: 10.1016/j.fbj.2016.11.001.

[43] P. Chiwamit, S. Modell, and R. W. Scapens, "Regulation and adaptation of management accounting innovations: The case of economic value added in Thai stateowned enterprises," Manag. Account. Res., vol. 37, pp. 30-48, Dec. 2017, doi: 10.1016/j.mar.2017.03.001.

[44] I. Gorze, "Managing Complexity: A Discussion of Current Strategies and Approaches," vol. 27, no. 15, pp. 438-444, 2015, doi: https://doi.org/10.1016/S22125671(15)01018-7.

[45] R. Hoitash and U. Hoitash, "Measuring Accounting Disclosure Complexity with XBRL," SSRN Electron. J., vol. 23529, no. 2, pp. 1-45, 2014, doi: 10.2139/ssrn.2433677.

[46] L. Hodder, P. E. Hopkins, and D. A. Wood, "The Effects of Financial Statement and Informational Complexity on Cash Flow Forecasts," 2006, doi: 10.2308/accr.2008.83.4.915.

[47] P. Cardozo, P. Morales-acevedo, A. Murcia, and A. Rosado, "Does the geographical complexity of the Colombian financial regulatory arbitrage, and funding costs 2 ," no. Xxxx, 2021, doi: 10.1016/j.jbankfin.2021.106076.

[48] B. Li, Z. Liu, W. Qiang, and B. Zhang, "J . Account . Public Policy The impact of XBRL adoption on local bias: Evidence from mandated U . S . filers," J. Account. Public Policy, vol. 39, no. 6, p. 106767, 2020, doi: 10.1016/j.jaccpubpol.2020.106767.

[49] R. Bushman et al., Financial accounting information, organizational complexity and corporate governance systems \$, vol. 37. 2004.

[50] Y. Chen, M. B. C. Menezes, and D. Ruiz-hern, "International Journal of Production Economics On the validity and practical relevance of a measure for structural complexity," vol. 240, no. June 2020, 2021, doi: https://doi.org/10.1016/j.ijpe.2021.108243.

[51] H. Rjiba, S. Saadi, S. Boubaker, and X. Sara, "Annual report readability and the cost of equity capital is," vol. 67, no. January, 2021, doi: doi.org/10.1016/j.jcorpfin.2021.101902.

[52] R. Korniichuk, "ScienceDirect ScienceDirect ScienceDirect Averaging and and Boosting Boosting Methods Methods in in Ensemble-Based Ensemble-Based 
Classifiers Classifiers for for Averaging Text Readability Readability Text," Procedia Comput. Sci., vol. 192, pp. 3677-3685, 2021, doi: 10.1016/j.procs.2021.09.141.

[53] J. J. Filzen, "Financial statement complexity and meeting analysts 'expectations," 2014.

[54] S. Durocher and A. Fortin, "J . Account . Public Policy Financial statement users ' institutional logic," vol. 40, 2021, doi: 10.1016/j.jaccpubpol.2021.106819.

[55] R. Chychyla, A. J. Leone, and M. Minutti-Meza, "Complexity of financial reporting standards and accounting expertise," J. Account. Econ., vol. 67, no. 1, pp. 226-253, Feb. 2019, doi: 10.1016/j.jacceco.2018.09.005.

[56] D. Pei and M. A. Vasarhelyi, "International Journal of Accounting Information Systems Big data and algorithmic trading against periodic and tangible asset reporting : The need for U-XBRL 设," Int. J. Account. Inf. Syst., vol. 37, p. 100453, 2020, doi: 10.1016/j.accinf.2020.100453.

[57] A. K. Ali and R. Badinelli, "Novel Integration of Sustainable and Construction Decisions into the Design Bid Build Project Delivery Method Using BPMN," Procedia Eng., vol. 145, pp. 164-171, 2016, doi: 10.1016/j.proeng.2016.04.038.

[58] B. Ben Lahouel, L. Taleb, Y. Ben Zaied, and S. Managi, "Business case complexity and environmental sustainability: Nonlinearity and optimality from an efficiency perspective," J. Environ. Manage., vol. 301, no. October 2021, p. 113870, Jan. 2022, doi: 10.1016/j.jenvman.2021.113870.

[59] T. Ahsan, B. Al-gamrh, and S. Sikandar, "Economic policy uncertainty and sustainable financial growth : Does business strategy matter?," Financ. Res. Lett., no. January, p. 102381, 2021, doi: 10.1016/j.frl.2021.102381.

[60] D. Alonso-martinez, V. De Marchi, and E. Di, "The sustainability performances of sustainable business models," vol. 323, no. January, 2021.

[61] S. Hadi and S. Baskaran, "Examining sustainable business performance determinants in Malaysia upstream petroleum industry," J. Clean. Prod., vol. 294, p. 126231, 2021, doi: 10.1016/j.jclepro.2021.126231.

[62] D. Higgins, T. C. Omer, and J. D. Phillips, "The Influence of a Firm's Business Strategy on its Tax Aggressiveness," Contemp. Account. Res., vol. 32, no. 2, pp. $674-$ 702, Jun. 2015, doi: 10.1111/1911-3846.12087.

[63] D. Lesmy and Y. Mugerman, "Doyoureadme? Temporal Trends in the Language Complexity of Financial Reporting," doi: 10.2139/ssrn.3469073.

[64] T. Virtanen, P. Parvinen, and M. Rollins, "Complexity of sales situation and sales lead performance: An empirical study in business-to-business company," Ind. Mark. Manag., vol. 45, no. 1, pp. 49-58, Feb. 2015, doi: 10.1016/j.indmarman.2015.02.024.

[65] D. T. W. Wong and E. W. T. Ngai, "Economic, organizational, and environmental capabilities for business sustainability competence: Findings from case studies in the fashion business," J. Bus. Res., vol. 126, no. April 2019, pp. 440-471, Mar. 2021, doi: 10.1016/j.jbusres.2020.12.060.

[66] W. Amann, C. Nedopil, and U. Steger, "The meta-challenge of complexity for global companies," J. Database Mark. Cust. Strateg. Manag., vol. 18, no. 3, pp. 200-204, 2011, doi: $10.1057 / \mathrm{dbm} .2011 .21$.

[67] W. Amann, C. Nedopil, and U. Steger, "The meta-challenge of complexity for global companies," J. Database Mark. Cust. Strateg. Manag., vol. 18, no. 3, pp. 200-204, Sep. 2011, doi: 10.1057/dbm.2011.21.

[68] M. Wagner, "How to reconcile environmental and economic performance to improve corporate sustainability: corporate environmental strategies in the European paper 
industry," J. Environ. Manage., vol. 76, no. 2, pp. 105-118, Jul. 2005, doi: 10.1016/j.jenvman.2004.11.021.

[69] K. Kluza, M. Ziolo, and A. Spoz, "Innovation and environmental, social, and governance factors influencing sustainable business models - Meta-analysis," J. Clean. Prod., vol. 303, p. 127015, Jun. 2021, doi: 10.1016/j.jclepro.2021.127015.

[70] S. Jakub, B. Viera, and K. Eva, "Economic Value Added as a measurement tool of financial performance," vol. 26, no. 15, pp. 484-489, 2015, doi: 10.1016/S22125671(15)00877-1.

[71] V. Berzakova, V. Bartosova, and E. Kicova, "Modification of EVA in Value Based Management," vol. 26, no. 15, pp. 317-324, 2015, doi: 10.1016/S22125671(15)00859-X.

[72] A. Ajina, M. Laouiti, and B. Msolli, "Research in International Business and Finance Guiding through the Fog: Does annual report readability reveal earnings management?," Res. Int. Bus. Financ., vol. 38, pp. 509-516, 2016, doi: 10.1016/j.ribaf.2016.07.021.

[73] Q. Xu, G. D. Fernando, and K. Tam, "Advances in Accounting Executive age and the readability of fi nancial reports," Adv. Account., vol. 43, no. April, pp. 70-81, 2018, doi: 10.1016/j.adiac.2018.09.004.

[74] M. B. Tudose, V. D. Rusu, and S. Avasilcai, "Performance Management for Growth: A Framework Based on EVA,” J. Risk Financ. Manag., vol. 14, no. 3, p. 102, Mar. 2021, doi: 10.3390/jrfm14030102.

[75] C. A. Cassell, L. M. Cunningham, and L. L. Lisic, "The Consequences of Writing Not So Readable Responses to SEC Comment Letters * The Consequences of Writing Not So Readable Responses to SEC Comment Letters," 2015. [Online]. Available: http://ssrn.com/abstract=2595661http://ssrn.com/abstract=2595661.

[76] R. Bushman, Q. Chen, E. Engel, and A. Smith, "Financial accounting information, organizational complexity and corporate governance systems," J. Account. Econ., vol. 37, no. 2, pp. 167-201, 2004, doi: 10.1016/j.jacceco.2003.09.005.

[77] V. R. Basili et al., "Linking Software Development and Business Strategy Through Measurement," Computer (Long. Beach. Calif)., vol. 43, no. 4, pp. 57-65, Apr. 2010, doi: 10.1109/MC.2010.108.

[78] P. Queen and O. Fasipe, "Understanding the Impact of Business Complexity on Executive Management Characteristics and Firm Performance," J. Account. Financ., vol. 15, no. 3, pp. 99-113, 2015.

[79] E. K. Lim, K. Chalmers, and D. Hanlon, "Journal of Accounting and Public Policy The in fl uence of business strategy on annual report readability," J. Account. Public Policy, vol. 37, no. 1, pp. 65-81, 2021, doi: 10.1016/j.jaccpubpol.2018.01.003. 